\title{
Developing Android-Based Game for L2 Learners in Language Knowledge
}

Novi Eka Susilowati, Universitas Negeri Malang, Indonesia, email: novi.eka.fs@um.ac.id, ORCID 0000-00022073-7275

Ariva Luciandika, Universitas Negeri Malang, Indonesia, email: ariva.luciandika.fs@um.ac.id, ORCID 00000002-6068-9415

Octi Rjeky Mardasari, Universitas Negeri Malang, Indonesia, email: octi.rjeky.fs@um.ac.id, ORCID 00000003-4369-253X

Yuniawatika, Universitas Negeri Malang, Indonesia, email: yuniawatika.fip@um.ac.id, ORCID 0000-00032395-7326

\begin{abstract}
The purpose of this study is to develop an android-based game for learning language knowledge material which includes Indonesian sound, vocabulary, and grammar because until now, there is no learning media that can be used by L2 learners in learning language knowledge. This developed product is aimed at Indonesian language for foreign speakers (Bahasa Indonesia untuk Penutur Asing/BIPA) learners. This research was conducted using Huang \& Soman's development model which consists of five stages, namely (1) understanding the target audience and the context, (2) define learning objectives, (3) structuring the experience, (4) identifying resources, and (5) applying gamification elements. The product developed has been validated by expert validation and validated by practitioner validation. The results showed that the product developed was feasible to be implemented with an average score of $87 \%$.
\end{abstract}

Keywords: Android-based game, Second language learning, language knowledge

Received: $15.11 .2020 \quad$ Accepted: 05.12.2020 $\quad$ Published: 14.01 .2021

\section{INTRODUCTION}

Currently, the interest of foreigners in learning Indonesian is increasing from time to time. This can be seen from the increasing number of foreigners studying Indonesian through the BIPA (Bahasa Indonesia untuk Penutur Asing/Indonesian for foreign speakers) program. Therefore, there are many institutions, both in Indonesia and in other countries, that organize BIPA programs.

One of the important aspects that learners of second language (and foreign languages) must learn is the aspect of language knowledge. The aspect of language knowledge is important to learn and master by second language learners because the aspect of language knowledge is very important as a basis for communicating using the target language and mastery of the aspect of language knowledge is one of the keys to the success of learning the target language. In fact, according to Gass \& Selinker (2001), a language learner is declared to acquire a second language if the learner master aspects of language knowledge.

The aspect of language knowledge consists of aspects of vocabulary and grammar. These two aspects are important aspects of mastering the target language because to be able to communicate and master the target language, a language learner must have a lot of target language vocabulary and master the structure of the target language. Kusmiatun, Suyitno, Widodo Hs, \& Basuki (2017) states that grammar and vocabulary are very important aspects related to language activities and are integrated with all the material studied in the target language. This means that when a language learner learns a second language, automatically he or she also learns the target language knowledge.

Suyitno (2017) states that language knowledge that needs to be mastered by second/foreign language learners is (1) vocabulary - both basic vocabulary and vocabulary formations -, and (2) sentences. Meanwhile, Rasouli, \& Jafari (2016) stated that there are three language components that are important for foreign language learners to master, namely vocabulary, pronunciation and grammar. Zhang (2012) states that vocabulary and grammar are indicators that can be used to measure learners' L2 proficiency.

Vocabulary is knowledge about the meaning of words (Hiebert \& Kamil, 2005). That is, vocabulary deals with the naming of a proposition and its meaning. Strickland, Galda, \& Cullinan (2007) stated that vocabulary is not only related to the naming of a thing, but also to give the name as well as the meaning / idea of the name. In the context of language learning, vocabulary is not only concerned with learning words 
and their meanings, but how a language learner recognizes the form of words and their meanings and how these words are chosen to refer to appropriate propositions.

Vocabulary is important to be taught and mastered by second language learners because foreign language learning can be said to be successful, one of which is measured by the learners' vocabulary mastery. In addition, vocabulary is an aspect that is very influential on students' understanding of the target language (Alqahtani, 2015). In fact, the research results of (Sujana, Sudika, Fitriana, \& Syahrial, 2018) show that $91 \%$ of BIPA teachers at the University of Mataram agree that vocabulary material is mandatory material taught explicitly in BIPA learning in each unit. This shows that vocabulary is an important thing that foreign language learners should learn.

Another aspect of language knowledge that foreign language learners must master is grammar. Donoghue (2009) defines grammar as a set of abstract rules in communication and underlies the structure of a language and every language has its own grammar that can be learned by language learners. That is why, foreign language learners need to learn grammar because sentences - which is the main material of grammar - are the language units used in communicating facts - people tend to communicate in the form of sentences. By mastering the target language sentence structure, a learner will easily understand the ideas conveyed using the target language. In fact, without a good knowledge of grammar, learners' language development will be severely constrained (Widodo, 2006). So, in learning any language, grammar learning is very important, especially since L2 learners' first language grammar is usually different from the grammar of the target language being studied. Therefore, to produce acceptable and correct sentences or utterances, people think to acquire grammar (Jung, 1999; Mufanti, Susilo, Gestanti, \& Nimasari, 2019).

In addition to vocabulary and sentences, in the context of BIPA learning, a language aspect that is no less important to learn is the sound aspect of Indonesian. In language, even though the sound symbol of a language is the same as the sound symbol of another language, the pronunciation may not be the same. For example, the sound /g/ in Indonesian is pronounced / $\mathrm{k} /$ in Chinese. This difference greatly affects whether or not learners pronounce vocabulary and sentences in the target language (Indonesian). Uysal \& Yavuz (2015) state that native-like proficiency in phonology is almost unachievable after 6 years old. In addition, the sound aspect of language is closely related to the meaning of the vocabulary or sentences that are pronounced because sometimes, there are differences in sounds that have implications for differences in meaning.

Language knowledge learning appears in various forms, for example using textbooks, question exercises, and integrating with four language skills (listening, speaking, reading, and writing) (Prihhartini, 2018). However, this kind of learning is deemed unable to arouse BIPA students' motivation. Moreover, BIPA students are adult learners and belong to digital native (Prensky, 2001) where they are very familiar with technology. In addition, BIPA students often face difficulties in learning language knowledge because their first language knowledge is different from knowledge of Indonesian. That is why, if learning is carried out monotonously and is textbook-based, learning will seem boring. In addition, the lack of teaching media used in the teaching and learning process improves the student's boredom (Murdiono, Suyato, Rahmawati, \& Aziz, 2020).

Based on the results of researchers' observations on the implementation of language knowledge learning, BIPA students often experience difficulties in learning language sounds, vocabulary, and grammar. This was evident from the students' low scores after they worked on language knowledge questions. In addition, BIPA students often mispronounce the sound of a language in a word so that they are also wrong in interpreting a word. Learners also often have difficulty changing active verbs into passive verbs.

Based on these conditions, a solution is needed that integrates the use of fun technology as well as can improve the ability of BIPA learners to explore language knowledge material which includes Indonesian sound, vocabulary, and grammar. As the 21st century moves forward, the field of second language learning and instruction has become more technology oriented (Flores, 2015; Gruss, 2016). This means that in the BIPA learning class which is a second language learning class, teachers need to present learning that is in accordance with the needs and characteristics of learners who are very close to technology.

The integration of technology in L2 learning has become essential because the integration of technology can contribute positively to the development of some personality factors, such as risk taking, increased motivation, and increased self-esteem. Technology integration in L2 learning has integrated new concepts to motivate learners in their pursue of achieving fluency. A concept that is adaptable to digital natives and digital immigrants that are learning a L2 is using game (Flores, 2015).

Huang \& Soman (2013) mentioned the use of games in providing intervention and improving outcomes as gamification. This gamification is closely related to emergent technologies (Flores, 2015). Gamification is also closely related to increased motivation and engagement which are usually required as 
prerequisites in completing a task or encouraging a behavior. That is why, for now, gamification is one of the popular ways to encourage a specific behavior (Huang \& Soman, 2013).

Richards, Platte, \& Platte (1992) explained that games are a set of organized activities that are usually equipped with several parts, namely certain tasks or goals, a set of rules, and competition between players, both internal players themselves or between one player and another. Based on this explanation, it can be seen that in games there is always a "competing" aspect. This competition can usually spur players' motivation to play the game. This aspect of competition can also bring out the entertainment aspect of the game. From the explanation of Richards, et al. It can also be seen that games not only provide entertainment, but games also provide clear objectives because of tasks or objectives that must be completed. Furthermore, Wiggins (2016) states that games can keep students' attention and motivation.

Using some types of word games in the second language (SL) classroom may be effective. In addition, Gruss (2016) stated that using game can serve the same general purpose focused on implementing fun in the FL classroom. Games can also help and encourage language learners to sustain their interest and work. In fact, Games can also help the teacher to create contexts in which the language is useful and meaning (Saraswati, 2015).

This game development research for BIPA learning is important to do with four considerations. First, BIPA learning is increasingly in demand by foreigners from year to year as proven by the increasing number of foreigners studying BIPA, both in their own country and in Indonesia. Second, during this time BIPA students often experience difficulties in learning language knowledge. Third, there is no technology-based learning media that can be used to teach Indonesian language knowledge to BIPA students. Fourth, so far there have been no games specifically developed for language knowledge learning, especially language knowledge games for BIPA students. So far what has been found is a game for learning English grammar so that the games available are not suitable for BIPA learning. This is reinforced by the statement of Nazar, Rusman, Putri, \& Puspita (2020) which states that not all apps are available on the market best fit some specific subjects.

The development of game media for learning Indonesian knowledge is expected to have a positive impact on BIPA students. By using games, it is hoped that the learning outcomes of BIPA students in the aspects of language knowledge can be improved. In addition, it is also hoped that the learning of BIPA knowledge can be more enjoyable so that the learning motivation of BIPA students can be increased which has implications for their learning outcomes. The use of games can also enable BIPA students to study anywhere and anytime because games can be developed using devices mobile (Crescente \& Lee, 2011). In fact, Salazar (2016) mentions that the use of technology plays and integral part in providing L2 learners a valuable language experience as they learn a second language.

\section{METHODS}

\section{Game Development Model}

Game development in this study uses the Huang \& Soman (2013) model. The development of the Huang \& Soman model game consists of five stages, namely (1) understanding the target audience and the context, (2) defining learning objectives, (3) structuring the experience, (4) identifying resources, and (5) applying gamification elements. The following is a game development diagram. 


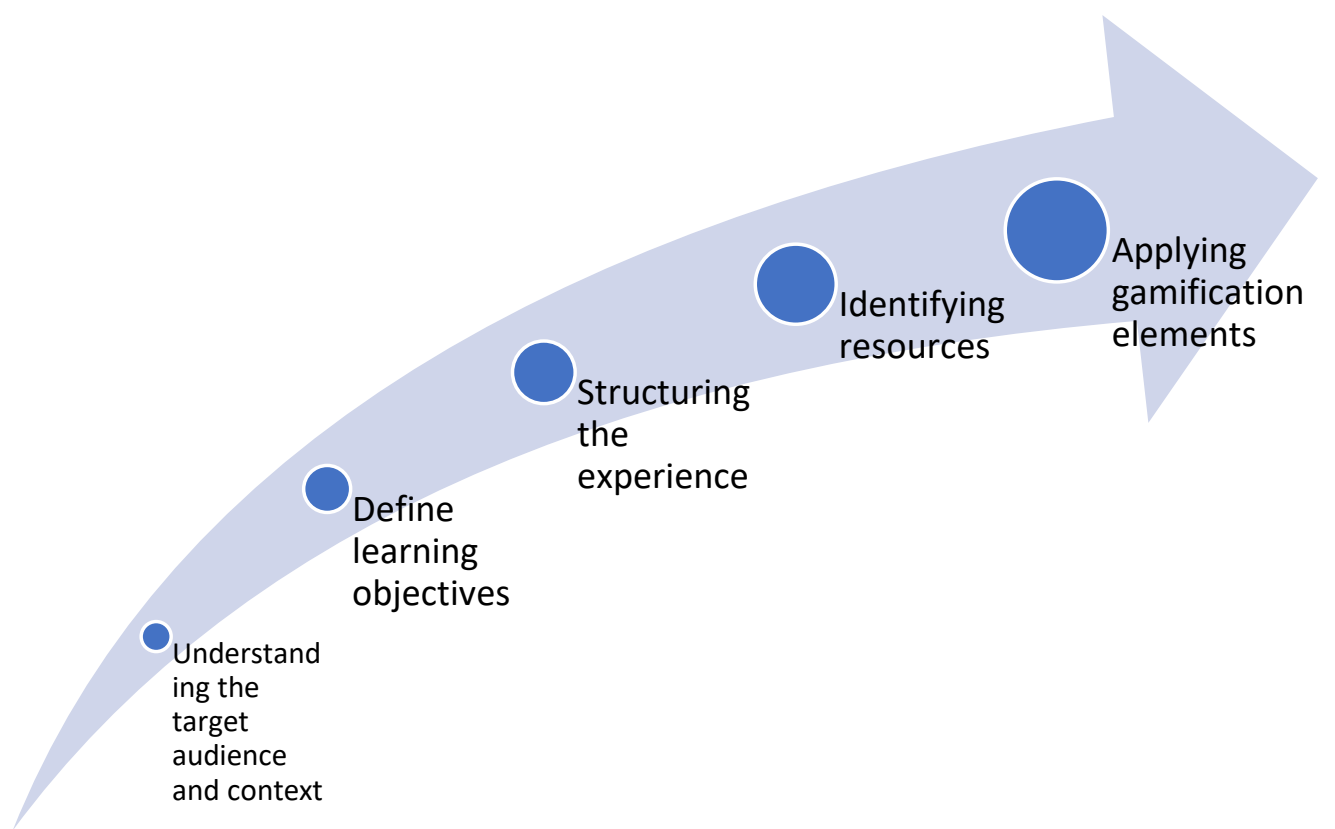

\section{Figure 1. Game Development Model}

At the stage of understanding the target audience and context, researchers identified the language characteristics of the target audience (BIPA students). At this stage, it is known that BIPA students who become the target audience are adult students with the age range 17-23 years. All target audiences are digital natives, all of whom are very familiar with technology. In terms of Indonesian language skills, all target audiences are Indonesian speakers who are still in the beginner stage. The target audience has difficulty distinguishing the sounds of the language $/ \mathrm{p} /$ and $/ \mathrm{b} /, / \mathrm{k} /$ and $/ \mathrm{g} /, / \mathrm{l} /$ and $/ \mathrm{r} /$, and $/ \mathrm{t} / \mathrm{and} / \mathrm{d} /$. At this stage, the researcher also identifies the context of game development, namely the game will be used for learning purposes.

At the stage of define learning objectives, the researcher identifies the target audience for BIPA learning objectives. Based on the identification results, two main objectives can be formulated, namely (1) conceptual goals, and (2) behavioral goals. Conceptual goals refer to the need for the target audience to master linguistic material which includes Indonesian sound material, changing active verbs into passive verbs, and their use in the context of Indonesian sentences. Behavioral goals refer to behaviors that you want to instill with the use of a developed game that includes concentration, answering all questions correctly, and accuracy.

In the structuring the experiences stage, the researcher identifies the learning experiences the target audience will undergo when playing the game. Learning experiences that can be undertaken by the target audience include differences in Indonesian sounds and their use in a word, identification of the basic forms of active and passive verbs, and changing the form of an active verb to a passive verb or vice versa. At this stage, the researcher collected words that sounded or written similarly and asked the target audience to choose the word according to the correct context. Researchers also collect verbs that have undergone a morphological process, especially verbs that have morphophonemic, then ask the target audience to determine their basic form. Then, the target audience is asked to change the verb into the active / passive form.

At the stage of identifying resources, the researcher determines the level of the game the target audience must master earlier before mastering the next level. The granting of this level is done so that the target audience really masters the easier question segments before entering the more difficult question segments. At this stage, the researcher also determines the instructions presented to the target audience and evaluates whether the instructions presented can be understood by the target audience and can measure the learning objectives. 
At the applying gamification elements stage, the researcher determines how to play the game: played individually or in groups. Based on the conclusion of observations and needs analysis, it can be determined that the game being developed will be played individually by the player. This is based on the consideration that the target audience is experiencing problems in the form of not understanding the material individually. Therefore, planting material concepts needs to be done individually as well. At this stage also, the researcher determines that to reach a higher level, the player must complete (answer all the questions correctly) before playing at the next level so that the game at a higher level will be locked until the player completes the previous level.

\section{Validation}

To get a game that is valid and ready for widespread use, the researcher validates the game. The validation test carried out includes the expert validation test and the practitioner validation test. The expert validation test consists of two kinds of validation, namely material validation and media validation. The material validation test was carried out to lecturers in the BIPA field, while the media validation was carried out to game experts. The practitioner validation is carried out to BIPA teachers.

Material verification is done to get data and input about the accuracy and suitability of the material / questions presented in the game. Media validation was carried out to obtain data and input on game quality and ease of operation of the game. Practitioner validation is used to obtain data and input about the possibility of games to be applied in BIPA learning.

During the validation test, validators are asked to install the game on their respective validator gadgets. After that, the validator is asked to play the game. After playing the game, the validator is asked to fill out a questionnaire containing 4 aspects of the question category, namely (1) content description, (2) presentation, and (3) language use. The content description aspect consists of 8 questions; the presentation aspect consists of 3 questions; the display aspect consists of 8 questions. The questions in this questionnaire are answered using a rating scale of 1-4 with the criteria (a) a value of 1 means that the game is not feasible and must be revised, (b) a value of 2 means that the game is not feasible and must be revised, (c) a value of 3 means game is feasible and needs to be revised, and (d) a value of 4 means the game is feasible and does not need to be revised. In addition, in the questionnaire there is also a column for the validator to provide comments, suggestions and verbal criticism of the game being validated.

\section{Data Analysis}

Filling in the questionnaire by the validator produces quantitative data and qualitative data. Quantitative data is obtained from filling in the questionnaire questions, a set of qualitative data gets comments, suggestions, and criticisms from the validator. The quantitative and qualitative data are used as the basis for revising the product and determining the feasibility of the product for implementation.

The quantitative data in this study were processed numerically using the following calculation formula.

\begin{tabular}{|l|}
\hline $\mathrm{P}=\frac{\sum \mathrm{x}}{\sum \mathrm{xi}} \mathrm{x} 100 \%$ \\
\hline Information: \\
$\mathrm{P}=$ Percentage \\
$\sum \mathrm{x}=$ The total number of validator answers \\
$\sum \mathrm{xi}=$ The total score \\
$100 \%=$ Constant \\
\hline
\end{tabular}

The results of the quantitative data calculation are used as a reference for determining product criteria. The determination of product criteria is carried out using the following scale.

Table 1. Determination of Product Eligibility and Revision

\begin{tabular}{|l|l|}
\hline Persentage Interval & Criteria \\
\hline $85 \%-100 \%$ & Very feasible and does not need revision \\
\hline $75 \%-84 \%$ & Feasible and needs to be revised \\
\hline $55 \%-74 \%$ & Not feasible and needs revision \\
\hline$<55 \%$ & Not feasible and must be revised \\
\hline
\end{tabular}




\section{RESULTS}

The results of this study are described based on research objectives which include (1) developing androidbased games for L2 students on language knowledge material, and (2) validating android-based games for L2 students on language knowledge material.

\section{Product Description Android-Based Game for L2 Learners on Language Knowledge Materials}

There are two games developed in this study. The first game is called Pilih Diksi, while the second game is called Tebak Aktif-Pasif. The game Pilih Diksi focuses on improving the ability to distinguish Indonesian sounds, while the game Tebak Aktif-Pasif focuses on increasing the ability to recognize and distinguish active and passive verb formations in Indonesian.

On the start screen of each game, there is a Start page and page Finish. On the next page, there is a game level menu. When you play for the first time, there is only one level that appears, namely Level 1. However, if the user has played more than once and has completed all the levels, the three levels will appear on this page. On every game page there is also a button Back. When finished answering, the information will immediately appear Correct or Incorrect on the user's answer choices.
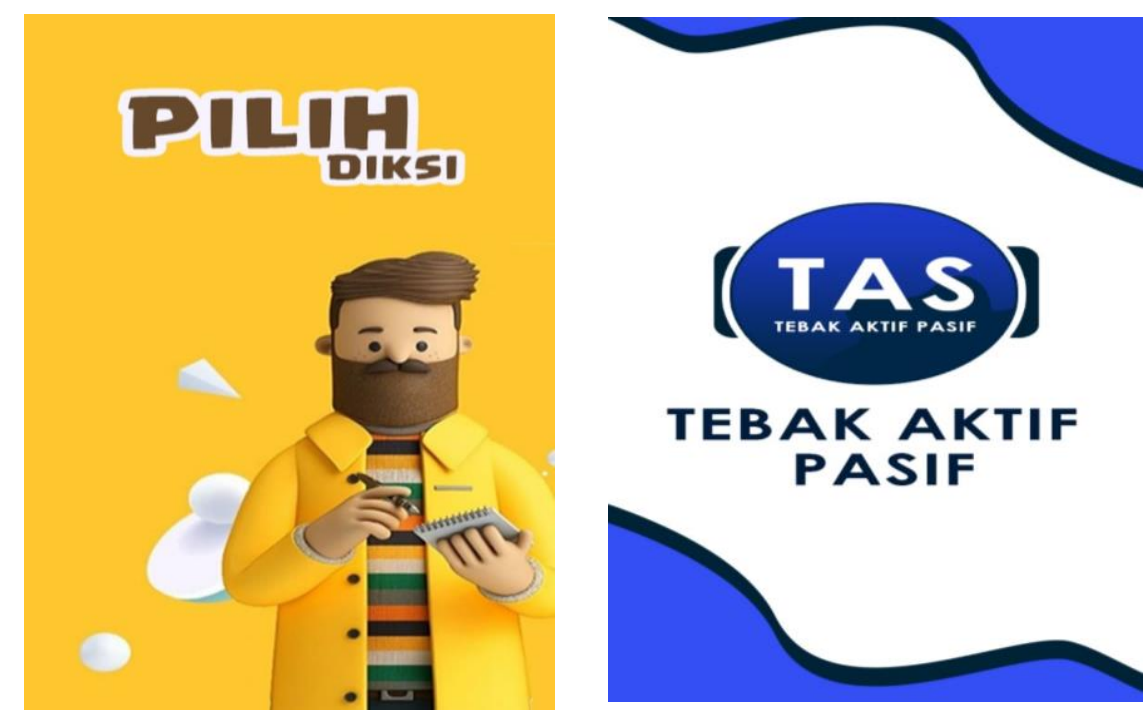

\section{TEBAK AKTIF PASIF}

Figure 2. Game Cover View
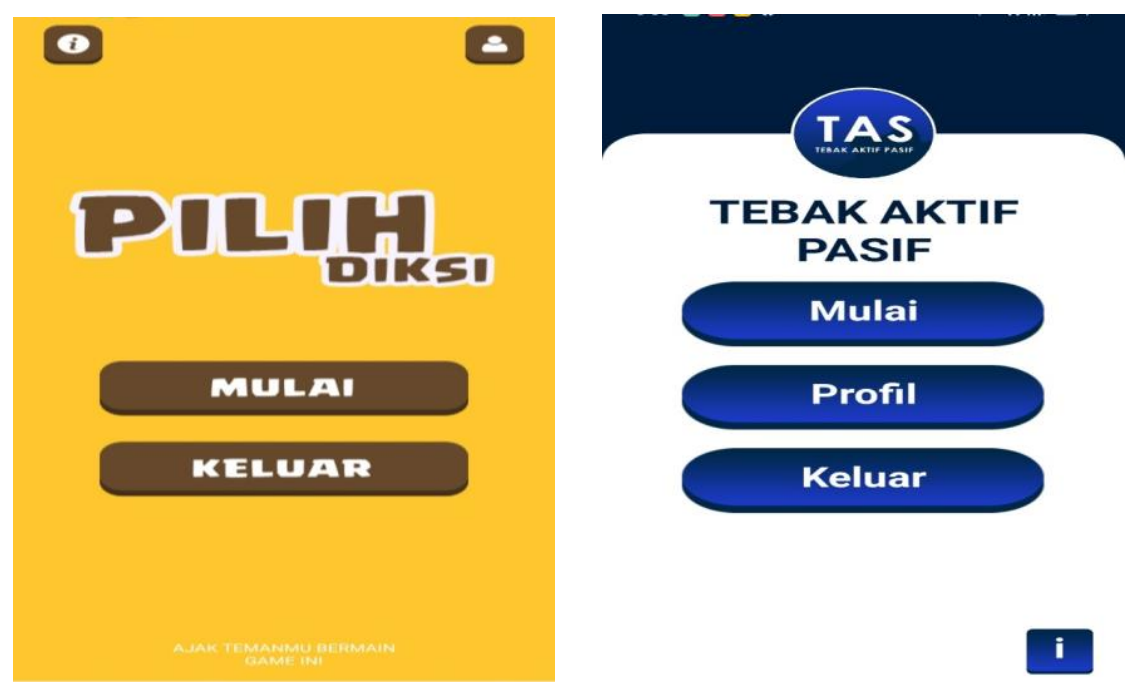

Figure 3. Game Start Page View 


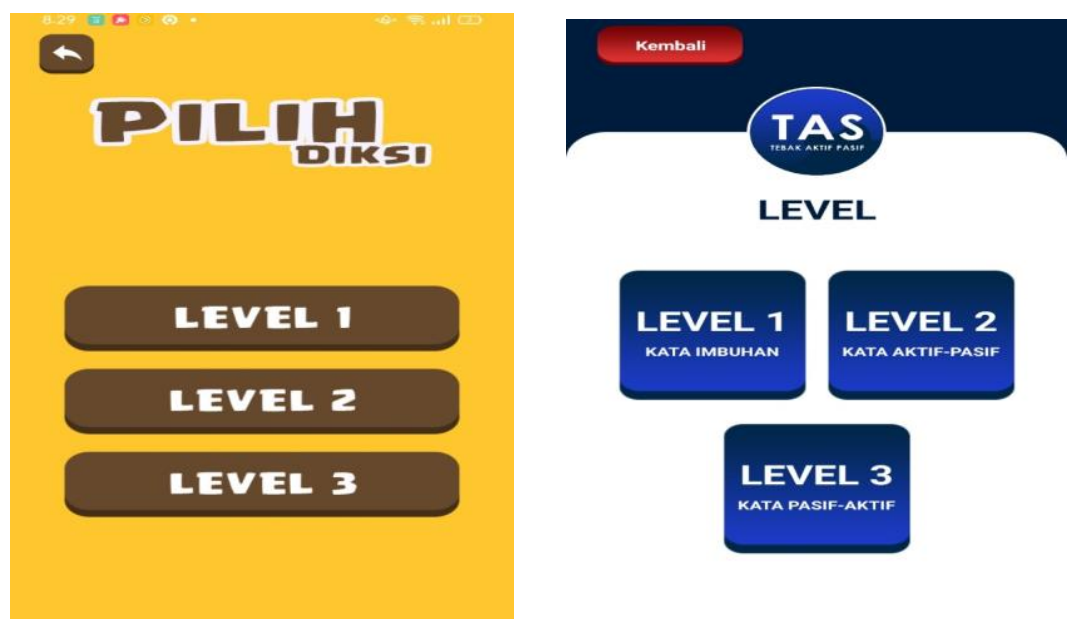

Figure 4. Game Level Page View

The game Pilih Diksi consists of three levels with different difficulty levels: the more the level, the more the difficulty level. In this game, words with similar language sounds are presented. Then, players are asked to choose the right words according to the context presented. At level 1 , two words that contain similar sounds and pictures are presented. Then, the user is asked to determine the right words according to the image presented. At level 2, two words are presented that contain similar sounds in a sentence context. Then, the user is asked to choose the right word according to the context of the sentence. At level 3,12 different words are presented. Then, the user is asked to look for words that are similar from the twelve words in the table.
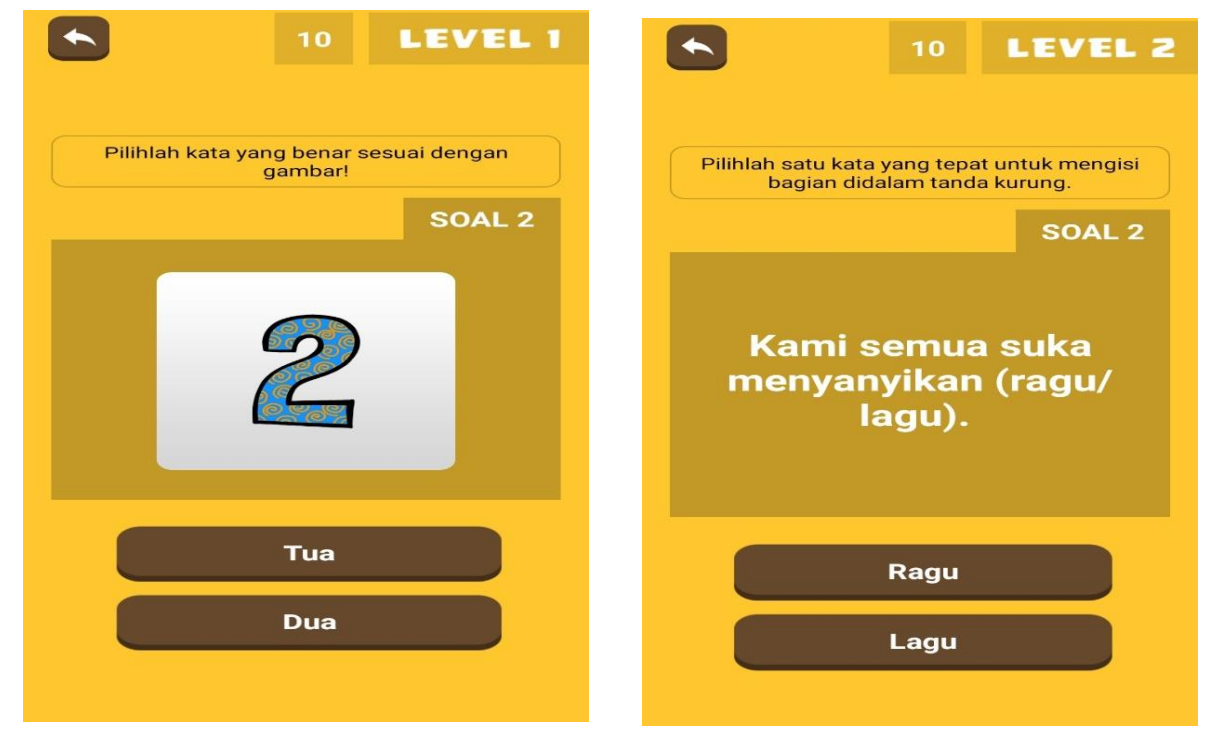

Figure 5 . Contents Page Display of Pilih Diksi Game

The game Tebak Aktif-Pasif also consists of three levels. At level 1, an active verb with presented $\mathrm{meN}$ - and a basic form is. Then, the user is asked to determine whether or not the basic form is presented. At level 2, pairs of active and passive verbs are presented. Then, the user is asked to determine whether the active verb is paired with the passive verb. At level 3, pairs of passive and active verbs are presented. Then, the user is asked to determine whether or not the passive verb is paired with the active verb. 


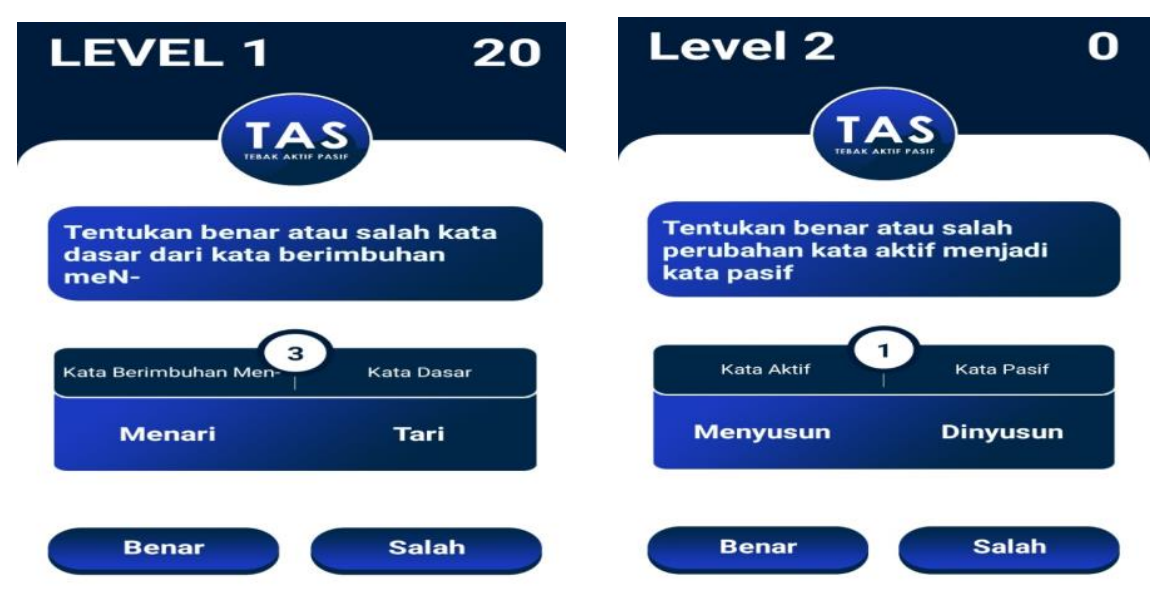

Figure 6. Contents Page Display of Tebak Aktif-Pasif Game

In both the games Pilih Diksi and Tebak Aktif-Pasif, for each correct answer, the user will get a score of 10. The game at a higher level is locked so that if the player wants to play at that level, the player must be able to complete (answer correctly) all the questions in the game previous level.

\section{Results of Android-Based Game Validation Test for L2 Students on Language Knowledge Materials}

There are two types of validation in developing this game, namely expert validation and practitioner validation. Expert validation consists of two types, namely validation of material experts and validation of media experts. Validation activities are carried out by giving a questionnaire containing 19 questions to the validator. In addition, validation activities are also carried out by asking the validators for comments, suggestions, and criticisms. Material expert validation is carried out to learning experts (BIPA). Media expert validation is carried out to android based game experts. Practitioner validation is carried out to BIPA teachers.

The following shows the results of filling out the questionnaire by the validators.

Table 2. Valıdation Test Results from The Aspect Description of Contents

\begin{tabular}{|l|l|l|}
\hline No & Questions & Result \\
\hline 1 & $\begin{array}{l}\text { Suitability of game content Pilih Diksi with content of teaching } \\
\text { materials }\end{array}$ & $92 \%$ \\
\hline 2 & Suitability of Tebak Aktif-Pasif game content withof teaching materials & $92 \%$ \\
\hline 3 & Accuracy of content of questions / instructions in the game Pilih Diksi & $67 \%$ \\
\hline 4 & $\begin{array}{l}\text { The accuracy of the contents of the questions / instructions in the } \\
\text { Tebak Aktif-Pasif game }\end{array}$ & $67 \%$ \\
\hline 5 & The accuracy of the answers in the game Pilih Diksi & $100 \%$ \\
\hline 6 & The accuracy of the answers in the Tebak Aktif-Pasif game & $92 \%$ \\
\hline 7 & $\begin{array}{l}\text { Suitability of the game content with the level of proficiency of BIPA } \\
\text { students with academic goals }\end{array}$ & $67 \%$ \\
\hline 8 & $\begin{array}{l}\text { Conformity game content with the aim of learning BIPA withacademic } \\
\text { goals }\end{array}$ & $100 \%$ \\
\hline & Average & $\mathbf{8 5 \%}$ \\
\hline
\end{tabular}

Table 3. Valıdation Test Results from The Aspect of Display

\begin{tabular}{|l|l|l|}
\hline No & Questions & Result \\
\hline 1 & The systematic clutter of game presentation at each level & $100 \%$ \\
\hline 2 & The systematic consistency of game presentation at each level & $92 \%$ \\
\hline 3 & The continuity between questions at each level & $67 \%$ \\
\hline & Average & $\mathbf{8 6 \%}$ \\
\hline
\end{tabular}


Table 4. Valıdation Test Results from The Aspect of Language Use

\begin{tabular}{|l|l|l|}
\hline No & Question & Result \\
\hline 1 & The accuracy of the sentence structure in the game & $92 \%$ \\
\hline 2 & The effectiveness of the sentences of the game & $92 \%$ \\
\hline 3 & The effectiveness of the spelling of the game & $92 \%$ \\
\hline 4 & The effectiveness of the punctuation of the game & $92 \%$ \\
\hline 5 & The standardization of words / terms used in the game & $92 \%$ \\
\hline 6 & The clarity of the explanation of the questions in the game & $92 \%$ \\
\hline 7 & The clarity of the instruction of the questions in the game & $67 \%$ \\
\hline 8 & $\begin{array}{l}\text { The suitability of the variety of languages used in the game } \\
\text { with the level of language proficiency of the learners }\end{array}$ & $92 \%$ \\
\hline & Average & $\mathbf{8 9 \%}$ \\
\hline
\end{tabular}

Based on the three validation results that have been carried out, the mean percentage of game assessment results is $87 \%$. With this average percentage, it can be concluded that the product is feasible to be implemented without revision. However, there are still minor suggestions from the validator in the form of (1) improving spelling and punctuation, and (2) improving the clarity of instructions on question work. The suggestions from the validator are used to improve the product so that the product being developed is truly feasible to be widely implemented.

\section{DISCUSSION AND CONCLUSIONS}

The rapid development of communication and information technology has implications for the world of learning. This condition of course implies the necessity for the world of learning to combine aspects of technology with pedagogy. This means that the world of learning must be able to combine and apply technological, pedagogical, and content knowledge (TPACK) in learning (Hofer \& Grandgenett, 2012). The combination of technology and pedagogy at the same time becomes a medium that is close to the life of the learners in which students are very familiar with technology.

Nowadays, games are common in the foreign language grammar classroom (Bush, 2015; Saaristo, 2015). This happens because current students are humans who were born in the 2000s and above, which means that they are included in the digital native group. This digital native group is very close to technology and technology has become a part of their daily life. In fact, most of these digital natives have gadgets. Furthermore, Singh \& Samah (2018) stated that learning through technology, especially through smartphone screens, is much more interesting for young people nowadays.

Yolageldili \& Arikan (2011) state that it should be born in mind that language learning is a challenging task requiring constant effort. Based on this explanation, android-based games are one of the appropriate media to use in the context of second language learning. The use of games can also help students to create enjoyment, motivation and reduce stress in learning grammar (Cam \& Tran, 2017). Wright, Betteridge, \& Buckby as quoted by Yolageldili \& Arikan (2011) states that games can provide meaningful learning so that games should not be positioned just as a pastime or for fun, however, games must be integrated into foreign language teaching programs.

The results showed that the android-based game developed in this study was feasible to implement. Moreover, until now on the market there has not been found a similar game specifically intended for BIPA students. The game of grammar/linguistic knowledge that exists so far is still a game for learning English grammar. This further strengthens the usefulness of the android-based game developed in this study.

In this android-based game developed, the researcher carefully chooses the vocabulary, sentence structure, and types of exercises presented so that the practice questions presented are in accordance with the level of language skills and learning needs of students. This is in line with the findings of Yolageldili \& Arikan (2011) and Nedomová (2007) which state that teachers must really choose and decide the appropriateness of the level and difficulty of games with students' language skills so that the games developed can make it difficult for students if the games are beyond their level of ability. speaking students. In fact, if the teacher is not able to choose well, games can become very boring and cannot achieve learning goals.

The game that was developed has indeed received good marks from the validators. However, there are still notes/comments from the validator, especially regarding the rules in the game. According to the validator, the rules in the game are less explicit and a little confusing. In fact, rules in the game play a very important role so that the game can run well. Yolageldili \& Arikan (2011) research results found that $80 \%$ 
of the EFL teachers feel uncomfortable when they do not teach grammar by explicitly giving the grammar rules.

Android-based games are a medium that can be used to teach language knowledge, which so far seems difficult and boring. This product is also a medium that suits the characteristics of students who are digital native, where they are familiar with the use of technology in their daily lives. This android-based game development is also a form of combining aspects of technology, pedagogy, and material content in learning. The use of Android as a basis for product development brings the advantage of being able to use this product anytime and anywhere so that students can use this product more freely.

The development of android-based games in this study is focused on learning Indonesian sound material and the formation of active/passive verbs and their changes. The results of the validation test show that the android-based game developed in this study is feasible to be implemented with the score obtained is $87 \%$.

\section{ACKNOWLEDGEMENT}

This research has been funded by Hibah Penerimaan Negara Bukan Pajak (PNBP) or Non-Tax Revenue Grant. We would like to send our gratitude to the research assistant for their great efforts in this project. We also thank the families and colleagues for their participation and support throughout this study.

\section{REFERENCES}

Alqahtani, M. (2015). The Importance of Vocabulary in Language Learning and How To Be Taught. International Journal of Teaching and Education, III(3), 21-34. DOI: 10.20472/TE.2015.3.3.002.

Bush, J. (2015). The Impact of Classroom Games on the Acquisition of Second Language Grammar. LIF Language in Focus Journal, 1(2), DOI: 10.1515/lifijsal-2015-0007.

Cam, L., \& Tran, T. M. (2017). An Evaluation of using Games in Teaching English Grammar for First Year English-Majored Students at Dong Nai Tech-nology University. International Journal of Learning, Teaching, and Educa-tional Research, 16(7), 55-71.

Crescente, M. L., \& Lee, D. (2011). Critical Issue of M-learning: Design Models, Adoption Processes and Future Trends. Journal of the Chinese Insti-tute of Industrial Engineers, 112-123.

Donoghue, M. (2009). Language Arts. USA: Sage Publication Inc.

Flores, J. F. (2015). Using Gamification to Enhance Second Language Learning. Digital Education Review, 27, 32-54. http://greav.ub.edu/der/.

Gass, S., \& Selinker, L. (2001). Second Language Acquisition: An Introduc-tory Course. London: Lawrence Erlbaum Associates.

Gruss, J. (2016). Games as a Tool for Teaching English Vocabulary to Young Learners. World Scientific News, 53(2), 67-109. Available online at www.worldscientificnews.com.

Hiebert, E., \& Kamil, M. (2005). English Teaching and Learning Vocabulary: Bringing Research to Practice. New Jersey: Lawrence Erlbaum and Associ-ates.

Hofer, M., \& Grandgenett, N. (2012). TPACK Development in Teacher Education. Journal of Research on Technology in Education, 45(1), 83-106. DOI:10.1080/15391523.2012.10782598.

Huang, W. H., \& Soman, D. (2013). A Practitioner's Guide to Gamifi-cation of Education. Toronto: Rotman School of Management University of Toronto.

Jung, J. (1999). Second Language Reading and the Role of Grammar. TESOL \& Applied Linguistics, 9(2), 2948.

Kusmiatun, A., Suyitno, I., Widodo Hs, \& Basuki, I. A. (2017). Identifying Features of Indonesian for Speakers of Other Languages (Bipa) Learning for Academic Purposes. International Journal of Social Sciences \& Educational Studies, 3(4), 197-207.

Mufanti, R., Susilo, A., Gestanti, R., \& Nimasari, E. (2019). A Constructing and Analyzing Model for the Teaching of Grammar. Asian EFL Journal, 23(3.2), 159-169.

Murdiono, M., Suyato, Rahmawati, E., \& Aziz, M. (2020). Developing an Android-Based Mobile Application for Civic Education Learning. International Journal of Interactive Mobile Technologies (iJIM), 14(16), 180-193.

Nazar, M., Rusman, Putri, I., \& Puspita, K. (2020). Developing an Android-Based Game for Chemistry Learners and its Usability Assessment. International Journal of Interactive Mobile Technologies (iJIM), 14(15), 111-124.

Nedomová, A. (2007). Teaching Grammar to Young Learners. Czech Republic: Unpublished master thesis. Masaryk University, http://is.muni.cz/th/44537/pedf_b/bachelor_thesis.pdf. 
Ojeda, F. A. (2004). The Role of Word Games in Second-Language Acqui-sition: Second-Language Pedagogy, Motivation, and Ludic Tasks. Unpublished disertation. Florida: University of Florida.

Prensky, M. (2001). Digital Natives, Digital Immigrant, Part II: Do They Really Thing Differently? On the Horizon, 9(6), 1-9.

Prihhartini, S. (2018). Learning Grammar Through Physical Games. SUKMA: Jurnal Pendidikan, 2(2), 187 203. https://doi.org/10.32533/02202.2018.

Rasouli,, F., \& Jafari, K. (2016). A Deeper Understanding of L2 Vocabu-lary Learning and Teaching: A Review Study. International Journal of Language and Linguistics, 4(1), 40-46.

Richards, J., Platte, J., \& Platte, H. (1992). Dictionary of Language Teaching and Applied Linguistics. London: Longman.

Saaristo, P. (2015). Grammar is The Heart of Language: Grammar and Its Role in Language Learning Among Finnish University Students. In J. Jalkanen, E. Jokinen, \& P. Taalas (Eds),. Voices of Pedagogical Development - Expanding, Enhancing and Exploring Higher Education Language Learning (s. 279318). içinde Dublin: Research-Publishing.net. doi:10.14705/rpnet.2015.000296.

Salazar, D. (2016). Introducing Game-Based Learning to Develop Grammar Skills in Elementary Students. Thesis unpublished. Pereira: Universidad Tecnológica de Pereira: Facultad de bellas artes y humanidades Licenciatura En Lengua Inglesa.

Saraswati, D. (2015). The Use of Board Game to Improve Students' Grammar Mastery (A Classroom Action Research on The Eight Grade of SMP N 1 Bergas in The Academic Year Of 2014/2015). A GRADUATING PAPER. Salatiga: English Education Department of Teacher Training and Education Faculty State Institute for Islamic Studies (IAIN) Salatiga.

Singh, M., \& Samah, N. (2018). Impact of Smartphone: A Review on Positive and Negative Effects on Students. Asian Social Science, 14(11), 83.

Strickland, D., Galda, L., \& Cullinan, B. (2007). Language Arts: Learning and Teaching. USA: Thomson Wadsworth.

Sujana, I. M., Sudika, I. N., Fitriana, E., \& Syahrial, E. (2018). Designing a Curriculum for Teaching Indonesian as a Foreign Language (TIFL) in Lombok (Indonesia) in-Country Program. The Philologist, 2, 1-22.

Suyitno, I. (2017). Norma Pedagogis Pembelajaran Bahasa Indonesia untuk Penutur Asing. Bandung: Refika Aditama.

Uysal, N. D., \& Yavuz, F. (2015). Teaching English to Very Young Learners. Procedia - Social and Behavioral Sciences, 197, 19-22.

Widodo, H. (2006). Approaches and Procedures for Teaching Grammar. English Teaching: Practice and Critique, 5(1), 122-141.

Wiggins, B. (2016). An Overview and Study on the Use of Games, Simulations, and Gamification in Higher Education. International Journal of Game-Based Learning, 6(1), 18-29. DOI: 10.4018/IJGBL.2016010102.

Yolageldili, G., \& Arikan, A. (2011). Effectiveness of Using Games in Teaching Grammar to Young Learners. Elementary Education Online, 10(1), 219-229.

Zhang, D. (2012). Vocabulary and Grammar Knowledge in Second Language Reading Comprehension: A Structural Equation Modeling Study. Modern Language Journal, 96(4), 558-575. 